\title{
The ecclesiastical patrons of Le Bec
}

\author{
Richard Allen
}

If the abbey of Le Bec owed its humble origins, and later many of its most important benefactions, to members of the lay aristocracy and lesser nobility in Normandy, England, and France, ${ }^{1}$ it also counted among its supporters a wide range of ecclesiastical figures, from archbishops and abbots to archdeacons and local priests. This chapter will examine the roles played by these individuals in the development of Le Bec from the abbey's foundation to the middle of the 13th century. This period, as has long been noted, saw Le Bec's early expansion coincide with that of the Norman - then Anglo-Norman - realm, ${ }^{2}$ with the main thrust of this growth being driven by the personalities of Lanfranc (1010-89) and St Anselm (1033-1109), ${ }^{3}$ two ecclesiastical heavyweights whose networks of influence stretched well beyond the walls of their nascent community located in the valley of the Risle. Although the rise of the new monastic orders in the second half of the 12th century saw the start of a gradual decline in Le Bec's status as the region's pre-eminent monastic institution, it nevertheless remained one of the most powerful Norman abbeys, whose extensive temporal wealth helped to underpin its central spiritual purpose. Crucial to the establishment and expansion of this wealth were members of the ecclesiastical hierarchy throughout the Anglo-

\footnotetext{
1 On this subject see, principally, Histoire, I, 30-474; Lemarignier/Lamon/Gazeau, "Monachisme et aristocratie", pp. 100-07; Gazeau, "Le domaine continental du Bec", pp. 259-71; Vaughn, The Abbey of Bec, pp. 1-59; Gazeau, “L’aristocratie autour du Bec”, pp. 89-103; Gazeau, “The Effect of the Conquest”, pp. 13142; Potter, "The Benefactors of Bec", pp. 175-92. See also Julie Potter's contribution to the present volume, 000 .

${ }^{2}$ Vaughn, The Abbey of Bec, pp. 1-2.

${ }^{3}$ On Lanfranc, the standard works are Gibson, Lanfranc of Bec; Cowdrey, Lanfranc. For St Anselm, see Southern, Saint Anselm.
} 
Norman realm and beyond. Archbishops and bishops, some of whom had connections to Le Bec either as a result of their careers or kinship networks, were not only occasionally benefactors themselves, granting land, revenues, and other benefices, but were responsible for confirming similar donations made by others to the abbey, thereby engendering, as a confirmation charter of John, bishop of Lisieux (1107-41), makes clear, the same recognition by the monastic community as that reserved for donors themselves. ${ }^{4}$ Abbots at other religious houses, on the other hand, among whom were those who had begun their career at Le Bec, either continued to exert an influence over the abbey following their departure, ${ }^{5}$ or played a part, along with their brethren, in Le Bec's links of confraternity, which themselves acted as a conduit for further patronage. ${ }^{6}$ Finally, the 12th and 13th centuries saw members of the lower clergy begin to act as patrons of the abbey, although their lesser status means the surviving records in this regard are comparatively sparse.

No such problem exists when it comes to the most important ecclesiastical patrons of Le Bec during this period. Members of the episcopate, both in Normandy and England, as well as elsewhere, played a vital - if sometimes contentious - role in the life of the abbey. Bishops were, of course, an essential element in the organization of powers in medieval society, and through their consecration were alone responsible for the conferring of holy

\footnotetext{
${ }^{4}$ In return for the general confirmation issued in 1134 by the bishop for the abbey's possessions located in his diocese, the abbot and monks agreed, among other things, to celebrate funeral services for the bishops of Lisieux is if they were one of their own, to inscribe their names among those of the monks of Bec, and to celebrate their anniversaries in perpetuity; see Histoire, I, 353-54. On the recognition of benefactors in the necrologies of Le Bec, and for the full text of the charter of the bishop of Lisieux, see Potter, "The Friendship Network of Le Bec”, I, 21-22, 33-46; ibid., II, no. 249.

5 For discussion with regards to Robert de Torigni, abbot of Mont-Saint-Michel, see Benjamin Pohl's contribution to the present volume, 000 .

${ }^{6}$ Potter, "The Friendship Network of Le Bec", I, 132-62, 214-68.
} 
orders, the blessing of altars and sanctified places, and the confection of holy oils, among other things. It is little wonder, therefore, that they should appear in the story of Le Bec from the very outset. Indeed, it was through the intercession of Herbert, bishop of Lisieux (c.102346), that the abbey took its first steps, since it was he, according to various later authors, who not only conferred upon the knight Herluin the habit of a monk, but also consecrated him as priest, appointed him abbot, and dedicated the primitive abbey church then established at Bonneville. ${ }^{7}$ Although Herbert's precise origins are unknown, the bishop was purportedly a "kinsman" (propinquus) of the Norman dukes, ${ }^{8}$ and it was such familial connections that not only ensured Le Bec gained the support of the ducal family, but also explained in part, according to the author of the De libertate Beccensis monasterii, why Herbert had been able to act as he did with regards to an institution located in a diocese outside his own. ${ }^{9}$

Indeed, the absence of the archbishops of Rouen in Le Bec's early history is marked enough to be noteworthy, although much of what we know about the abbey's origins in this regard is open to question, as the work of Jean-Hervé Foulon has shown. ${ }^{10}$ Moreover, the archbishops of Rouen were not completely uninvolved in the abbey at this time. It was with the consent (consentio) of Archbishop Robert (989-1037), who has otherwise been shown to have been an extremely active patron of monastic houses, ${ }^{11}$ that Herluin gave the initial

\footnotetext{
${ }^{7}$ Gilbert Crispin, Vita Herluini, p. 192; Chronique, pp. 1-2; "Les courtes annales du Bec”, p. 95; OV, III, 12; GND, II, 60, 64; RT, I, 38; De libertate, p. 138.

${ }^{8}$ De libertate, p. 138. For discussion of Herbert's career, see Allen, “The Norman Episcopate”, I, 248-59.

${ }^{9}$ De libertate, p. 138. On this treatise, see Vanderputten and van Houts's respective contributions to the present volume, 000 .

${ }^{10}$ Foulon, “Le chevalier Herluin”, pp. 563-607; Foulon, “La liberté du Bec”, pp. 57-83. See also Jean-Hervé Foulon's contribution to the present volume, 000.

${ }^{11}$ For Robert's career, see Allen, "Praesul praecipue, atque venerande", pp. 153-83.
} 
parcel of lands on which Le Bec was founded. ${ }^{12}$ His successor, Mauger (1037-1054/55), on the other hand, not only dedicated the primitive abbey church, but allusions in a synodal letter also suggest that there was perhaps some link between the archbishop's milieu and the monastic school then under the guidance of Lanfranc at Le Bec. ${ }^{13}$ Connections between Lanfranc and the next occupant of the archiepiscopal see were to prove even stronger, since Archbishop Maurilius (1055-67), who was also apparently close to St Anselm, ${ }^{14}$ was himself a former monk of reforming ideals with Italian links, active in the same circles as the prior of Le Bec. ${ }^{15} \mathrm{He}$ can be found alongside Lanfranc shortly after his election to the archiepiscopate, ${ }^{16}$ immediately using his newfound authority to join the prior of Bec in opposing the teachings of Berengar of Tours (before 1010-88), ${ }^{17}$ and it was perhaps with Lanfranc's encouragement that Maurilius gave to Abbot Herluin (1034-78) "a richly decorated reliquary" (unum magnum ornatum gemmis) containing the hair of the Virgin Mary. ${ }^{18}$ In any event, it was no doubt such acts of generosity that led the community at Le Bec to honor the archbishop of Rouen with first place in the list of their confraternity, ${ }^{19} \mathrm{a}$ document which, it has been suggested, may have formed part of a commemorative "Le Bec

\footnotetext{
${ }^{12}$ Recueil des actes, no. 98 (version B).

${ }^{13}$ For discussion, see Allen, “Avant Lanfranc”, pp. 135-36.

${ }^{14}$ According to the Vita Anselmi, Maurilius gave counsel to St Anselm, not only causing him to become a monk, but also playing some role in his rise to the English primacy; see Eadmer of Canterbury, Life of Anselm, pp. 11$12,21-22$.

15 For Maurilius, see De Boüard, "Notes et hypothèses sur Maurille", pp. 81-92; Allen, "The Norman Episcopate”, I, pp. 325-42.

${ }^{16} \mathrm{OV}, \mathrm{II}, 66$.

17 The archbishop convened a council at Rouen in 1055 at which a Eucharistic profession of faith was promulgated; see Somerville, "The case against Berengar of Tours", pp. 57-58, note 11.

${ }^{18}$ Histoire, I, 653.

${ }^{19}$ Potter, "The Friendship Network of Le Bec", I, 272 (Appendix A).
} 
Liber vitae". ${ }^{20}$ Maurilius is also remembered in both the abbey's necrology, which may have likewise been bound in the same Liber vitae, and that of the priory of Saint-Nicaise de Meulan, where he is described as "our brother" (frater noster $)^{21}$

But it is not until the reign of his successor, John of Ivry (1067-79), that evidence survives of direct archiepiscopal contributions to the expansion or protection of Le Bec's landed wealth. John, who had previously been bishop of Avranches (1060-79), was himself a member of one of the most powerful families in the duchy. His father was Rodulf, the uterine brother of Duke Richard I (942-96), and also the count of Ivry. Archbishops Robert and Mauger were John's cousins, while he was half-brother to Hugh, bishop of Bayeux (c.101149), as well as uncle to William fitz Osbern, an important Le Bec benefactor, and Osbern, bishop of Exeter (1072-1103). ${ }^{22}$ John was also an active patron of Le Bec before his election to the episcopate. Upon his father's death, it appears that he inherited estates situated on the Risle near Saint-Philbert, ${ }^{23}$ which although important, were small in comparison with his brother Hugh's patrimony. It was nevertheless from these holdings that John granted to Le Bec various possessions, including the church of Saint-Georges-du-Vièvre, ${ }^{24}$ along with its tithe and that of the bourg, and the island at Pont-Authou with its various appurtenances. ${ }^{25}$ As archbishop, John contributed to these initial gifts with the donation of a mill on the river

\footnotetext{
${ }^{20}$ Pohl, “The 'Bec Liber Vitae”, pp. 357-360.

${ }^{21}$ Potter, "The Friendship Network of Le Bec", I, 305 (Appendix B); Obituaires de Sens, II, 240.

${ }^{22}$ On John’s life and career, see Allen, “‘A Proud and Headstrong Man”, pp. 189-227.

${ }^{23}$ Saint-Philbert-sur-Risle, Eure, cant. Pont-Audemer.

${ }^{24}$ Saint-Georges-du-Vièvre, Eure, cant. Beuzeville.

${ }^{25}$ Pont-Authou, Eure, cant. Pont-Audemer. These donations are recorded in the record of grants issued for Le Bec in 1077. John is referred to in this document as "John, son of count Rodulf", suggesting that the charter from which this information was taken was issued before his election to the bishopric of Avranches in 1060; see
} Regesta(b), no. 166 . 
Risle, which William, bishop of Évreux (c.1046-66), had held from him, ${ }^{26}$ while a letter of St Anselm seems to suggest that the archbishop was somehow involved in the grant made by his nephew, William fitz Osbern, of a tract of land near the abbey. ${ }^{27}$ John is also the only member of the Norman episcopate with whom Lanfranc is known to have maintained a sustained correspondence, writing to him on at least five occasions. ${ }^{28}$ Unfortunately, an attack of apoplexy in July 1077 rendered the archbishop paralyzed, and although evidence suggests he continued to occupy his position until at least early 1079, he was unable to participate, even it seems as an observer, in either the dedication of the abbey church on 23 October 1077, or the benediction of Anselm as abbot on 22 February $1079 .{ }^{29}$ John would nevertheless spend his final days in the abbey's shadow, for he would retire to his estates at Saint-Philbert a few months before his death on 9 September $1079 .{ }^{30}$ His generosity towards Le Bec ensured his commemoration as part of the abbey's confraternity, in which his name is listed only second to that of his predecessor, and in Le Bec's necrology. ${ }^{31}$

It was the next archbishop, however, whose relationship with Le Bec would prove among the most significant. William Bona Anima (1079-1110), the son of a former bishop of Sées, had previously been a member of the Rouen chapter under Maurilius, then a monk at

\footnotetext{
${ }^{26}$ Paris, Bibliothèque nationale de France, MS Lat. 12884, fol. 178r: Johannes archiepiscopus Rothomagensis dedit molendinum super Rislam quod Guillelmus episcopus Ebroicensis de eo tenuerat. terram de Ramsoneto ex dono Willelmi filii Osberni. Sally Vaughn interpreted this to mean that the "archbishop of Rouen had previously granted to the abbey a certain estate from the gift of William fitz Osbern", see Vaughn, The Abbey of Bec, p. 35; also cf. Vaughn, Anselm of Bec, p. 58.

${ }^{28} \operatorname{Letters}(b)$, nos. 14-17, 41.

${ }^{29}$ For this part of John's career, see Allen, ““A Proud and Headstrong Man’”, pp. 215-17.

${ }^{30}$ Allen, "The Acta archiepiscoporum", p. 45.

${ }^{31}$ Potter, “The Friendship Network of Le Bec", I, 272 (Appendix A), 306 (Appendix B).
}

27 Anselm of Canterbury, Opera omnia, III, 216 (= no. 89): Mortuo enim archiepiscopo Johanne quaerimus 
Le Bec under Lanfranc, whom he followed to Saint-Étienne de Caen, eventually succeeding him as abbot. ${ }^{32}$ In the years following his departure, the abbey of Le Bec had grown in wealth and prestige, in part under the guidance of St Anselm, ${ }^{33}$ who had also taken steps to maintain the abbey's exceptional level of institutional independence, including in relation to the archbishops of Rouen. Seizing on the "vacancy" caused by Archbishop John's incapacitation, Anselm seemingly sought to push through his investiture as abbot, even going so far as to seek out the king-duke at the siege of Gerberoy in the process, with the result that he was eventually installed without having to profess obedience to the archbishop. ${ }^{34}$

It was also during Anselm's abbacy that William Bona Anima granted to the abbey of Le Bec his famous privilege of exemption, which freed the monastery and its parish from all episcopal exactions, except in those cases pertaining exclusively to the office of the bishop. ${ }^{35}$ The issuance of this privilege, which essentially allowed Le Bec to exercise in its own name the jurisdiction of an archdeacon over its own parish, a right that no other Norman monastery would enjoy before the middle of the 12 th century, ${ }^{36}$ has traditionally been understood in the context of a protracted dispute. But while the text of the privilege itself makes clear that Anselm was raising "certain plaints and claims" (querelas quasdam et calumnias) with regards to the issue, and Archbishop William's archiepiscopate is characterized by clashes

\footnotetext{
${ }^{32}$ On William's career, see Spear, “William Bona Anima”, pp. 51-60; Gazeau, Normannia monastica, II, 4143; Allen, "The Norman Episcopate", I, 366-98.

${ }^{33}$ Histoire, I, 106-233; Vaughn, The Abbey of Bec, pp. 23-41; Vaughn, Anselm of Bec, pp. 51-67. See also Véronique Gazeau's contribution to the present volume, 000. For an alternative view, see Southern, Saint Anselm, pp. $183-84$.

${ }^{34}$ Vaughn, Anselm of Bec, pp. 54-56.

${ }^{35}$ The text of this exemption is edited in the Appendix to this article.

${ }^{36}$ Treatises, p. 18.
} 
over exemption with other monastic institutions, ${ }^{37}$ the eventual terms reflect not those of the "treaty" between fractious parties imagined by Sally Vaughn, ${ }^{38}$ but rather a compromise between two men who throughout their careers maintained an intimate relationship based on mutual respect and cooperation. ${ }^{39}$ The privilege does not touch upon the question of a profession of obedience, an issue that Archbishop William would press some three years later, ${ }^{40}$ but instead sets out the liberties to be enjoyed by Le Bec, while also clearly stating the archbishop's rights and securing certain concessions from Anselm. Unlike William's dealings with monastic exemption elsewhere in Normandy, neither the duke nor the papacy seem to have been brought in to arbitrate, and it is hard to imagine that the archbishop, although a keen defender of archiepiscopal rights, would have issued the exemption grudgingly. Le Bec was his old house, Anselm his old friend, and the archbishop lent his support to both when they needed his help, ${ }^{41}$ while it cannot have escaped William's attention that as abbot of Saint-Étienne de Caen he had secured a similar agreement from Odo, bishop of Bayeux (c.1049-97). ${ }^{42}$ Whatever the circumstances behind the privilege, it represented one of the

\footnotetext{
37 For discussion of the archbishop's various disputes with the abbey of Fécamp, see Musset, "Notules fécampoises", p. 597.

${ }^{38}$ Vaughn, The Abbey of Bec, p. 38; Vaughn, Anselm of Bec, p. 61. Vaughn's understanding of the charter is coloured by a misreading of the section concerning the rights reserved to the archbishop, which she mistakenly interprets as those being granted to the abbey.

${ }^{39}$ On the two men's relationship, see Allen, “The Norman episcopate”, I, 390-93.

${ }^{40}$ Vita Willelmi, p. 718.

${ }^{41}$ The archbishop sent a letter in support of Le Bec's claims concerning tithes and rights at Liancourt-SaintPierre (Oise, cant. Chaumont-en-Vexin); see Dufour, “Un faux de Louis VI”, pp. 56-57 (= no. 3).

${ }^{42}$ Vaughn, Anselm of Bec, p. 62.
} 
most important contributions to life at Le Bec, and was later confirmed by at least three of William's successors. ${ }^{43}$

It was with similar grace, to borrow the expression of Julie Potter, that the archbishop acquiesced to Abbot William's (1093-1124) reluctance to profess obedience during his benediction, ${ }^{44}$ and although the episode provoked from Bona Anima a rare display of emotion, he was soon placated by the new abbot of Le Bec, who spoke so eloquently that he earned his lasting affection. ${ }^{45}$ Outside of such issues, William played a role in the expansion of the Le Bec network, and it was with his blessing (consensu) that the priory of Saint-Pierre de Pontoise was established, ${ }^{46}$ although his relationship with the monks there was not always a smooth one. ${ }^{47} \mathrm{He}$ also "conceded and confirmed" (concedere et confirmare) to the abbey the church of Notre-Dame d'Émendreville, seat of the priory of Notre-Dame du Pré, which had originally been given by Robert Curthose. ${ }^{48}$ If William interacted with Le Bec in the later years of his reign then nothing is known about it, but his earlier contributions ensured his

\footnotetext{
${ }^{43}$ According to the notes made by Dom Jouvelin, the charter was confirmed by Hugh d'Amiens (1130-64), Rotrou of Warwick (1165-83) and Walter of Coutances (1184-1207), see Paris, Bibliothèque nationale de France, MS Lat. 13905, fols. 38v, 90r, printed in Potter, "The Friendship Network of Le Bec”, I, nos. 291, 444, 480. According to these same notes, the confirmation of Archbishop Hugh was found in one of the abbey's cartularies, although it was seemingly not that for which a fragment of the table of contents still survives, which only lists the confirmation of Archbishop Rotrou (Évreux, Archives départementales de l'Eure, 2 F 2121, fol. $7 \mathrm{v})$.

${ }^{44}$ Potter, “The Friendship Network of Le Bec”, I, 209.

${ }^{45}$ Milo Crispin claims Bona Anima was initially "angry" (iratus) as a result of William's refusal, see Vita Willelmi, p. 718.

${ }^{46}$ Histoire, I, 393, note 5.

${ }^{47}$ William was reprimanded by the pope in 1094 for preventing the monks from ringing their bells after the second hour of Mass; see Urban II, Epistolae et Privilegia, p. 374 (= no. xcviii).

${ }^{48}$ Haskins, Norman Institutions, p. 293 (Appendix F, no. 1).
} 
remembrance in necrologies associated with the abbey. ${ }^{49}$ Strangely, however, his name is not among those of the abbey's confraternity.

In fact, it is William's successor, Geoffrey Brito (1111-28), who, for compositional reasons rather than anything else, is the last occupant of the archiepiscopal see to be named in the confraternity list that has come down to us. ${ }^{50}$ A prelate who was both politically and religiously astute, ${ }^{51}$ his interactions with Le Bec are limited but not without importance, and it was no doubt his intervention in the dispute between Abbot Boso (1124-36) and Henry I (1100-35) concerning the swearing of homage that earned Geoffrey his place not only among the abbey's confraternity, ${ }^{52}$ but also in its necrology. ${ }^{53}$ The evidence is slightly more plentiful for his successors, and shows that each in his turn contributed to life at the abbey. Hugh d'Amiens (1130-64), for example, despite his dispute with Abbot Theobald (1136-38) concerning a profession of obedience, issued various charters confirming the abbey's possessions, and also granted to Le Bec free passage for its boats at Vézillon, an important right already enjoyed by several other Norman abbeys. ${ }^{54}$ Elsewhere, it was with Hugh's counsel (consilium) that Hugh IV, count of Montfort, established the priory of Saint-Ymer, showing again the important intermediary role members of the episcopate could play in acts

\footnotetext{
${ }^{49}$ Potter, “The Friendship Network of Le Bec”, I, 292 (Appendix B); Obituaires de Sens, II, 238.

${ }^{50}$ Potter, "The Friendship Network of Le Bec", I, 272 (Appendix A). This list seems to have been compiled before 1154; see ibid., p. 34.

${ }^{51}$ For Geoffrey’s career, see Spear, “Geoffrey Brito”, pp. 123-37.

52 The story of Geoffrey's involvement in this affair is told in both the De libertate and the Vita Bosonis, the latter of which refers to the archbishop as "wise and respected" (prudens et honorandum); see De libertate, pp.
} 156-62; Vita Bosonis, pp. 727-29.

${ }^{53}$ Potter, "The Friendship Network of Le Bec”, I, 311 (Appendix B).

${ }^{54}$ Waldman, "Hugh of Amiens”, no. 10; Potter, “The Friendship Network of Le Bec”, I, 129. 
of monastic patronage. ${ }^{55}$ Among the other bishops to offer their advice on this matter was Rotrou, bishop of Évreux (1139-65), a close relative of two of Le Bec's most generous patrons, ${ }^{56}$ and who, following his election as archbishop of Rouen (1165-83), not only granted certain indulgences on the occasion of the dedication of the abbey church, which he performed on 19 March 1178 in the presence of Henry II (1154-89) and two of his sons, ${ }^{57}$ but also confirmed, like Archbishop Hugh before him, the exemptions granted by William Bona Anima. ${ }^{58}$ Walter of Coutances (1184-1207) likewise confirmed the same privilege, ${ }^{59}$ although not much else is known of his interaction with the abbey, ${ }^{60}$ not only because the surviving evidence is fragmentary at best, but also because he, like his immediate successor, Robert II (1208-21), tended to favor Cistercian houses. ${ }^{61}$ Walter and Robert II are nevertheless honored in the abbey's necrology, as are Archbishops Hugh and Rotrou. ${ }^{62}$

Of course, Le Bec's network of episcopal patrons stretched far beyond the diocese of Rouen. The abbey enjoyed the support of bishops throughout the Anglo-Norman realm and

\footnotetext{
${ }^{55}$ Cartulaires de Saint-Ymer, p. 3 (= no. II).

${ }^{56}$ Rotrou was a brother of Robert du Neubourg and cousin of Waleran II de Meulan; see Spear, The Personnel of the Norman Cathedrals, p. 134.

${ }^{57}$ Chronique, pp. 21-22, note 1.

${ }^{58}$ Potter, “The Friendship Network of Le Bec”, II, no. 444. For Hugh's confirmation, see Waldman, "Hugh of Amiens", no. 9b.

${ }^{59}$ Potter, "The Friendship Network of Le Bec”, II, no. 480.

${ }^{60}$ Much of what survives is in fragmentary form. See Potter, "The Friendship Network of Le Bec”, II, nos. E15, LG8, NDP17; Cartulaires de Saint-Ymer, no. XVIII. There is a slim possibility that the Walter de Coutances (Walterus de Const') who appears in a charter of Giles, bishop of Evreux (1170-79), is the future archbishop of Rouen; see Potter, “The Friendship Network of Le Bec”, II, no. 421, where this toponymnic is misidentified as “de Const[ance]".

${ }^{61}$ For Walter and Robert II, see Tabbagh, Fasti Ecclesiae Gallicanae, pp. 77-80.

62 Potter, "The Friendship Network of Le Bec", II, 299, 310-11 (Appendix B).
} 
beyond, even maintaining strong connections with individuals in dioceses seemingly located well outside of Le Bec's ambit of influence. It was to the ancient parish of Saint-Samson-surRisle that Baldric de Bourgueil, archbishop of Dol (1107-30), retired at the beginning of the 12th century, ${ }^{63}$ from where he visited Le Bec and was accorded a warm welcome, with his name subsequently being inscribed in both the abbey's necrology and that of the priory of Meulan. ${ }^{64}$ Likewise, the neighboring bishops of Avranches, despite being charged with the smallest, poorest and most westerly diocese in Normandy, maintained close links with Le Bec, largely as a result of their manor at Saint-Philbert-sur-Risle. Situated less than 10km from the abbey, and virtually within spitting distance of one of its priories, it was Bishop John of Ivry who had originally granted the manor to his cathedral, with the site slowly developing across the 11 th and 12 th centuries,${ }^{65}$ often as a direct result of interaction with Le Bec. Bishop Michael (1068-94), for example, reached an agreement with Abbot Anselm, a fellow Italian, ${ }^{66}$ concerning a bridge the bishop wished to build on the abbey's lands at Fontaine Cour ${ }^{67}$ with the resulting structure, known in the 12 th century as "the bridge of the bishop of Avranches" (pons episcopi Abrincensis), later supplying the abbey with important revenues from its toll. ${ }^{68}$ Bishop Turgis (1094-1134), on the other hand, was able to secure lands at Fontaine Cour in exchange for some at Pont-Authou, thereby adding to Le Bec's not

\footnotetext{
${ }^{63}$ Today, Saint-Samson-de-la-Roque, Eure, cant. Bourg-Achard.

${ }^{64}$ Potter, “The Friendship Network of Le Bec”, I, 313 (Appendix B); Obituaires de Sens, II, 242.

${ }^{65}$ For the history of this residence, see Casset, Les évêques aux champs, pp. 451-62.

${ }^{66}$ For Michael, see Allen, "Robert Curthose”, pp. 89-92.

${ }^{67}$ Allen, "Un évêque et sa ville", pp. $48-49$ (= no. IV). Fontaine Cour, Eure, cant. Pont-Audemer, com. Glossur-Risle.

${ }^{68}$ Histoire, I, 353.
} 
inconsiderable possessions there. ${ }^{69}$ It was at Saint-Philbert that Bishop Herbert (1153-60) blessed Robert de Torigni, then prior of Le Bec, as the new abbot of Mont Saint-Michel, ${ }^{70}$ and it was at Le Bec that Herbert chose to be buried, ${ }^{71}$ perhaps as a result of his association with the Empress Mathilda, one of the abbey's great patrons, ${ }^{72}$ whom he had previously served as chaplain. ${ }^{73}$ His predecessor, Richard de Beaufou (1134-42), similarly chose the abbey as his final resting place, no doubt because of his familial connections, which saw him related not only to other Le Bec patrons, such as his episcopal predecessor, John of Ivry, but also to those who had taken the habit within the abbey's walls. ${ }^{74}$ The study of the favored burial places of certain families has revealed that such practices were designed, first and foremost, to show familial stability and permanence, ${ }^{75}$ as well as serving as a direct invocation to the monks to intercede. ${ }^{76}$ But such a sense of durability and lasting connection was also no doubt beneficial to the abbey, as it helped to solidify its role and status within the wider network of relationships of which it formed an important part, and offered a physical manifestation of the spiritual rewards from which potential benefactors might profit.

\footnotetext{
${ }^{69}$ Évreux, Archives départementales de l'Eure, 2 F 2121, fol. 117v: Ego Turgisus, gratia Dei, Abrincatensis episcopus, dedi et sigillo meo confirmavi ecclesie Becci arpentum prati apud Pontem Altoi, pro excambio quarumdam insularum de terra de Fonteincurt que satis parve erant juxta molendinum meum, ipsi tamen
} molendino multum necessarie. Testes ex parte nostra, et cetera.

${ }^{70} R T$, I, 284-285.

${ }^{71}$ Ibid., p. 328.

${ }^{72}$ Chibnall, "The Empress Matilda", pp. 35-48.

${ }^{73} R T$, I, 279.

${ }^{74}$ The bishop was a descendant of Richard de Beaufou, whose son, Robert, took the habit of Le Bec towards the end of the 11th century. A Richard de Beaufou was prior at the abbey during Bishop Richard's episcopate; see Histoire, I, 340, note 3.

75 Golding, "Burials and Benefactions”, pp. 64-75; Golding, “Anglo-Norman Knightly Burials”, pp. 35-48.

${ }^{76}$ Postles, "Monastic Burials", pp. 620-37. See also Julie Potter's contribution to the present volume. 
Unsurprisingly, both Richard and Herbert are listed in Le Bec's necrology, ${ }^{77}$ as are two of their 13th-century successors, William IV Burel (1210-36) and William V de Sainte-MèreÉglise (1236-53), with the former being specifically identified as "our benefactor" (benefactor noster). ${ }^{78}$ The nature of William's benefaction is unfortunately unknown, but it was perhaps associated with Saint-Philbert, given its role in relations between the bishops and the abbey.

Episcopal devotion to Le Bec could also manifest itself in other forms. We have already noted how Archbishop William Bona Anima intervened on the abbey's behalf in a dispute with another monastery (see above), and it was on account of the great affection (benevolentia) that Ivo, bishop of Chartres (1089-1115), felt for St Anselm that he stood similarly in support of Le Bec's cause, ${ }^{79}$ an act that no doubt accounts in part for his appearance in the abbey's necrology ${ }^{80}$ Other bishops held Le Bec in such regard that they sought to retire there. Philip de Harcourt, bishop of Bayeux (1142-63), who was a close follower of the great Le Bec patron, Waleran de Beaumont, count of Meulan (1104-66), ${ }^{81}$ apparently expressed a desire to become a monk at the abbey, but died before he could do so, instead leaving to the monks his impressive library. ${ }^{82}$ Books counted among the many gifts

\footnotetext{
${ }^{77}$ Potter, “The Friendship Network of Le Bec”, I, 303, 306 (Appendix B).

${ }^{78}$ Ibid., pp. 293, 309 (Appendix B).

${ }^{79}$ The bishop claimed to have intervened on Le Bec's behalf in a dispute with abbey of Molesme; see Anselm of Canterbury, Opera omnia, IV, no. 181.

${ }^{80}$ Potter, "The Friendship Network of Le Bec", I, 313 (Appendix B). Robert de Torigni claimed Ivo was a student of Lanfranc's and that he studied at Le Bec, although not all are convinced; see Rolker, Canon Law and Ivo of Chartres, pp. 90-91.

${ }^{81}$ Crouch, The Beaumont Twins, p. 45.

${ }^{82}$ Histoire, I, 93-94. The catalogue of books given to Le Bec by Philip is printed in Ravaisson, Rapports au ministre de l'Instruction publique, pp. 389-95. For an edition and commentary, see Laura Cleaver's contribution
} to the present volume, 000 . 
Lanfranc sent to Le Bec following his election as archbishop of Canterbury, and were important both in terms of the abbey's intellectual prestige and in reinforcing its bonds of fraternity with other houses ${ }^{83}$ Philip, moreover, was not the first bishop of Bayeux to look to spend his final days at Le Bec, since his predecessor, Turold (1097/99-1107), had retired to the abbey as a monk following a somewhat difficult reign that eventually ended in his deposition by the pope. ${ }^{84}$ A generous benefactor of the abbey while bishop, ${ }^{85}$ it was $\mathrm{St}$ Anslem who encouraged Turold's monastic ambitions, counselling his "dearest friend" (amicus carissimus) to remove his person from the secular way of life so that his mind "might be separated from worldly thought, and might always be occupied with good things and spiritual contemplation". ${ }^{86}$ Turold clearly took this advice to heart. Abbey texts remembered the former bishop, who remained at Le Bec for more than forty years, as "a very venerable man", even "holy", ${ }^{87}$ while a letter of Honorius II (1124-30), which was sent to Richard son of Samson (1107-33), recalled to the new bishop of Bayeux his "god-fearing" (timoratus)

\footnotetext{
${ }^{83}$ Potter, “The Friendship Network of Le Bec”, I, 224-26.

${ }^{84}$ For discussion, see Allen, "Robert Curthose”, pp. 96-98.

85 Turold, along with his brother, Hugh, gave to the abbey the churches of Saint-Laurent and Notre-Dame d'Envermeu (Seine-Maritime, cant. Dieppe-2); see Allen, “The Norman Episcopate”, II, no. 35.

${ }^{86}$ Anselm of Canterbury, Opera omnia, V, 363-64 (= no. 418): Sicut igitur corpus vestrum est segregatum a saecularium conversatione: sic cor vestrum sit separatum a mundana cogitatione, et sit semper occupatum aliqua utili et spirituali meditatione.

${ }^{87}$ For references to Turold's holiness, see the Le Bec necrology, which calls him the "pious bishop of Bayeux" (pius Baiocensis episcopus) (Potter, “The Friendship Network of Le Bec”, I, 311, Appendix B) and a miracle story relating to St Foy, preserved in Rome, Biblioteca Apostolica Vaticana, MS Reg. lat. 499, fol. 161r, and Paris, Bibliothèque nationale de France, MS Lat. 5427, fol. 125r: Fuit nostris temporibus vir valde venerabilis, Turoldus nomine, germanus Hugonis Evremodensis, pontifex ordinatus Baoicassine urbis... Hanc vero miseriam vir sanctus, pudore optimo decorates.... For discussion of the Vatican manuscript, of which I have only seen photocopies, see Delisle, "Notice sur vingt manuscrits", pp. 519-27.
} 
predecessor. ${ }^{88}$ Nearly a century after Turold's arrival, it was another run-in with papal authority that led Hugh de Nonant, bishop of Coventry (1188-98), to take up the habit at Le Bec and to bequeath to the abbey part of his worldly goods. ${ }^{89}$

Other prelates, if they did not wish to join the community in a physical sense, sought to create links with Le Bec that ensured their commemoration as part of the abbey's network of confraternity. We have already noted how John, bishop of Lisieux, upon issuing a general confirmation for Le Bec in 1134 negotiated in return the promise of funeral services and anniversaries, with the monks duly inscribing his name in their necrology. ${ }^{90}$ At the same time, John also secured the celebration of a general office for the canons of Lisieux, which a list of churches in fraternity with Le Bec confirms took place on 2 January each year. ${ }^{91}$ The same list records that three offices were to be said for the bishops of Beauvais and the canons of Évreux. ${ }^{92}$ The origins of the former are unclear, although at least one bishop of Beauvais had previously been a monk at the abbey, ${ }^{93}$ while the latter was most likely instituted following the grant by Luke, bishop of Évreux (1203-20), which accorded to the abbot of Le Bec the title of canon of Évreux, a privilege that was confirmed by his successor, Richard de Saint-Léger (1223-36), a former abbot of Le Bec. ${ }^{94}$ More firmly established is the request

\footnotetext{
${ }^{88}$ Honorius II, Epistolae et Privilegia, p. 1276 (= no. lx). The letter is dated 6 May 1127.

${ }^{89}$ See Potter's contribution to the present volume, 000.

90 Potter, "The Friendship Network of Le Bec", I, 300 (Appendix B). He is also in the necrology of Saint-
} Nicaise de Meulan, Obituaires de Sens, II, 239.

${ }^{91}$ Histoire, I, 482; Potter, “The Friendship Network of Le Bec”, I, 325 (Appendix D).

${ }^{92}$ Histoire, I, 484; Potter, “The Friendship Network of Le Bec”, I, 326 (Appendix D).

${ }^{93}$ Namely, Bishop Fulk (1089-95), Gallia Christiana, XI, 711. Anselm also had close ties with the city; see Mews, “St Anselm”, pp. 106-19.

${ }^{94}$ MS Lat. 13905, fol. 10r; Histoire, I, 522. The charter, which is dated 3 November 1207, mentions various rites to be performed by the monks of Le Bec for the canons of Évreux, but does not talk specifically of "three offices" (tria officia). 
made by Reginald, bishop of Chartres (1182-1217), that he, along with his late father, Reginald, lord of Mousson (1149-70), and his mother, Agnes, be "received" (recipere) into the monk's fraternity and remembered in an anniversary in return for a gift of grain at Les Mureaux. ${ }^{95}$ Savaric, bishop of Bath and Wells (1192-1207), on the other hand, settled a dispute concerning the church of Old Cleeve, Somerset, by making it a prebend of Wells, granting the abbot and monks full fraternity in the church of Wells and promising to celebrate the obits of the abbots of Le Bec in the same way as those of the bishops. ${ }^{96}$

Of course, not every episcopal act granting or confirming benefices contained such stipulations. Individuals such as Ouen, bishop of Évreux (1113-39), Arnulf, bishop of Lisieux (1141-82), Froger, bishop of Sées (1159-1184/85), Geoffrey, bishop of Amiens (1104-15), Herbert Poore, bishop of Salisbury (1194-1217), and many others besides, all made or confirmed important donations to the abbey without seemingly requesting commemoration in return. ${ }^{97}$ Many of their names nevertheless appear in the Le Bec necrology, or in those of its dependencies, indicating that the monks wished to incorporate the bishops in the abbey's extensive circle of prayer, which served as the primary nexus through which the abbey was able to interact with the political, social, ecclesiastical and economic world outside its cloisters. It is therefore little wonder that the monks sought regularly to expand this network, which, if the numbers from the Le Bec necrology alone are counted, by the end of the 13th century included bishops and archbishops in dioceses

\footnotetext{
${ }^{95}$ MS Lat. 12884, fols. 252v-253r, printed in Potter, “The Friendship Network of Le Bec”, II, no. 510. Here, Reginald, lord of Mousson (de Moncione), is incorrectly identified as "count of Mortain". Les Mureaux, Yvelines, chef-lieu de cant.

${ }^{96}$ English Episcopal Acta, X, no. 196.

${ }^{97}$ Potter, “The Friendship Network of Le Bec”, II, nos. 226 (Ouen), 251 (Ouen), 339 (Geoffrey); Histoire, I, 335 (Ouen), 338 (Ouen), 391 (Ouen), 409 (Arnulf), 439 (Ouen); Évreux, Archives départementales de l’Eure, H 70 (Froger); English Episcopal Acta, XVIII, no. 193 (Herbert Poore).
} 
stretching from the Loire Valley to south central Wales, with particularly high numbers for those in Rouen, Évreux, and Avranches (Fig. 000). ${ }^{98}$ The same necrology also bears witness to the not insignificant number of prelates who had been elected to their see having previously been at Le Bec. The link between the abbey and various English cathedral communities, especially Canterbury, is well known, with the many exchanges of gifts and advice already examined in detail elsewhere. ${ }^{99}$

But it was not just within the episcopal network that Le Bec could find many of its former members. Within a little more than a century of its founding, the abbey had seen more than twenty of its monks elected to the heads of religious houses located throughout England and France. ${ }^{100}$ This included figures such as William Bona Anima, abbot of Saint-Étienne de Caen (1070-1079), later archbishop of Rouen; Gilbert Crispin, abbot of Westminster (10851117/18) and author of the Vita Herluini; and Robert de Torigni, abbot of Mont Saint-Michel (1154-86), whose influence over Le Bec is explored elsewhere in this volume. ${ }^{101}$ As this last comment suggests, the interaction of such individuals with the abbey, and their impact upon it, has largely been examined in detail elsewhere, with the result that only the essentials will be repeated here.

Let us first note that the installation of Le Bec monks in various houses throughout England and France gave the abbey unrivalled access to a network of exchange and patronage through which flowed everything from money to books and advice (Fig. 000), as Julie Potter has shown. ${ }^{102}$ The reputations of Lanfranc and St Anselm helped add houses to this network

\footnotetext{
${ }^{98}$ Ten pre-1300 archbishops of Rouen are commemorated in the necrology, and six bishops each of Évreux and Avranches; see Potter, “The Friendship Network of Le Bec”, I, Appendix B.

${ }^{99}$ Ibid., pp. 223-26.

${ }^{100}$ Ibid., p. 146, note 2.

${ }^{101}$ See Pohl's contribution to the present volume, 000 .

${ }^{102}$ Potter, "The Friendship Network of Le Bec", I, 223-40.
} 
in which Le Bec monks were not to be found, such as Saint-Germer-de-Fly and La ChaiseDieu, with the latter deliberately sending a delegation to negotiate the beginnings of bonds of confraternity between the two, which was sealed with an exchange of books. ${ }^{103}$ The abbey of Saint-Évroult, which had a longstanding association with Le Bec stretching back to the community's foundation, ${ }^{104}$ likewise sealed the bond of fraternity between the two houses with a gift, this time of possessions at Guernanville, ${ }^{105}$ where William fitz Osbern and the Tosny family, both early benefactors of Le Bec, had held lands, ${ }^{106}$ and which at the time of the gift itself formed part of the honor of Breteuil, which belonged to Robert II de Beaumont, earl of Leicester (1118-1167/68), twin brother to Waleran de Meulan. ${ }^{107}$ Such an act of confraternal patronage, therefore, was seemingly imbued with multiple layers of significance and not only sought to reinforce the bonds between Le Bec and Saint-Évroult, but also between Le Bec and its lay patrons. It is possible that similar considerations lay behind a grant to the abbey by William I, abbot of Lyre (after 1113 - before 1130), whose house had been founded by William fitz Osbern, ${ }^{108}$ although unfortunately the place in which the gift was located (Vetus Secretaria) cannot be identified. ${ }^{109}$ Evidence of similar grants among the surviving Le Bec charters is unfortunately lacking, although those copies and originals that remain represent only a fraction of what once existed. It is also clear that Le Bec enjoyed

\footnotetext{
${ }^{103}$ Ibid., p. 231.

${ }^{104}$ Ibid., pp. 232-33.

${ }^{105}$ Guernanville, Eure, cant. Breteuil. See MS Lat. 12884, fol. 191v, printed in Potter, "The Friendship Network of Le Bec", II, no. 267, where Guarlenvilla is misidentified as Guarlenville.

${ }^{106}$ Regesta(b), no. 166; Histoire, I, 348, note 2.

${ }^{107}$ On Earl Robert and the honour of Breteuil, see Crouch, The Beaumont Twins, pp. 108-12.

${ }^{108}$ Hockey, "William fitz Osbern”, pp. 96-105.

${ }^{109}$ Potter, "The Friendship Network of Le Bec", II, no. 268. It is possible that this is a mis-transcription of Vetus Lira (La Vieille-Lyre, Eure, cant. Breteuil).
} 
links with institutions outside of those named in the sources to survive from the abbey's archives, ${ }^{110}$ meaning it is possible that proof of similar acts of exchange and patronage waits to be discovered elsewhere.

A comparable lack of material affects what we know about patronage towards Le Bec by members of the lower ecclesiastical orders. Indeed, among the hundreds of abbey charters and charter extracts that survive for the 12th and 13th centuries, only a handful concern donations made by men of middling, low or minor ecclesiastical rank. Even when charters relating to such individuals can be identified, it is often difficult to determine what motivated a particular act of patronage, although certain trends can be identified. Proximity to the abbey itself, or an association with one of the churches in its possession, obviously played a fundamental role, and no doubt explains in part the donations made by individuals such as Richard Pepin, who was subsequently priest of Fourques then of Le Bec, ${ }^{111}$ and the clerks Thomas, son of Elias de Thierville, Robert de Brionne and Richard Rufus. ${ }^{112}$

It is likewise possible to identify links between those members of the lower clergy who counted among the abbey's benefactors and other Le Bec patrons. Joscelin Crispin, canon of Rouen, for example, who is listed in the abbey's necrology as "our devout friend

\footnotetext{
${ }^{110}$ For example, Le Bec is listed among the confraternity of the abbey of Saint-Julien de Tours; see Chevalier, Histoire de l'abbaye de Noyers, p. 316.

${ }^{111}$ Richard Pepin gave lands located in the parish of Le Gros-Theil (Eure, cant. Le Neubourg) and at Saint-Eloide-Fourques (Eure, cant. Brionne); see Évreux, Archives départementales de l'Eure, H 72 (act dated 1256); also Évreux, Archives départementales de l’Eure, H 91, fol. 11r (act dated 1254).

112 Thomas and Richard gave to the abbey lands at Thierville (Eure, cant. Pont-Audemer) and Saint-Philbert-surBoissey (Eure, cant. Bourgtheroulde-Infreville), respectively (acts dated 1231 and January 1256), while Robert granted, along with his father, a rent of 20 shillings (undated act, 13th century); see Paris, Bibliothèque nationale de France, MS Nouv. acq. lat. 1771, fols. 164r, 167r; Évreux, Archives départementales de 1’Eure, H 91, fol. 2r; Paris, Bibliothèque nationale de France, MS Lat. 9211, no. 20.
} 
and benefactor" (pius amator et benefactor noster), ${ }^{113}$ was undoubtedly a member of one of the abbey's most important patron families, although unfortunately both the nature and date of his benefaction are unknown. ${ }^{114}$ Others can be linked to the great Le Bec patron, Waleran de Meulan. It was Waleran who, in 1146, confirmed the grant made by Thomas, clerk of Pont-l'Évêque, of a house in Montfort-sur-Risle, which was then held by the count. ${ }^{115}$ Likewise, Ralph, son of Orielt, canon of Évreux, who in the late 1130s gave to the abbey his house and its site in Évreux, ${ }^{116}$ may have been the same person as Ralph de Montaure, who counted among Waleran's clerical followers. ${ }^{117}$ David Spear, on the other hand, has suggested that Ralph may have been the son of Fulk de Guernanville, dean of the chapter of Évreux. ${ }^{118}$ As Fulk's toponymic suggests, his family had links to a region that, as we have already seen, was closely associated with other Le Bec patrons, while another of his sons, Fulk, was prior of Saint-Évroult, a house with which the abbey maintained close links.

Whatever Ralph's origins, his connection with the Évreux chapter, which David Crouch has described as being at this time as almost akin to a Beaumont collegiate church, ${ }^{119}$ would have undoubtedly played a significant role in his donation, since its members were regular patrons of Le Bec. Archdeacons of Évreux proved particularly active benefactors. The donations of some, such as the archdeacon Luke, who was later dean then bishop of Évreux,

\footnotetext{
${ }^{113}$ Potter, "The Friendship Network of Le Bec", I, 311 (Appendix B).

114 The only member of the Crispin family to be listed in the various fasti of Rouen cathedral personnel is William Crispin, who was a canon in the 1240s; see Tabbagh, Fasti Ecclesiae Gallicanae, p. 195.

115 “Acts of Waleran II”, no. 17. Pont-l’Évêque, Calvados, chef-lieu de cant.; Montfort-sur-Risle, Eure, cant. Pont-Audemer.

116 Ibid., no. 13.

${ }^{117}$ Crouch, The Beaumont Twins, p. 154.

${ }^{118}$ Spear, The Personnel of the Norman Cathedrals, p. 136.

${ }^{119}$ Crouch, The Beaumont Twins, p. 154.
} 
represent part of a longstanding relationship with the abbey stretching across many years. ${ }^{120}$ Others can be found making their donation either in the presence of other Le Bec patrons, or having their gift confirmed by them. The archdeacon Richard Croc, for example, ceded to the abbey his rights over a house in Évreux, which he had received from Abbot Letard, with the act being witnessed by three men who were either themselves benefactors of Le Bec or close relations of those who were. ${ }^{121}$ Likewise, in 1135, the archdeacon William de Glos granted to the abbey the church of Saint-Laurent de Marnefer. ${ }^{122}$ Not only was William probably a member of the family that had previously held the provostry of Glos, ${ }^{123}$ situated in the honour of Breteuil and thus within the ambit of various Le Bec patrons, but the act was consented to by William Fresnel, who in the 1130s was a staunch supporter of Robert II de Beaumont. ${ }^{124}$ It was perhaps similar connections that inspired the archdeacon Roger de Brionne, who according to some was a kinsman of Rotrou, archbishop of Rouen, ${ }^{125}$ and thus a member of the Beaumont-Neubourg clan, to return to Le Bec the church of Le Theil-Nolent. ${ }^{126}$

But for every donation of this kind that can be linked in some way to the wider network of Le Bec patronage, there are those, such as the gift of land near Martot by Robert,

\footnotetext{
${ }^{120}$ As archdeacon, Luke granted to the abbey two thirds of the tithe at Granchain (Eure, cant. Bernay); see Mémoires et notes, II, 197.

121 Évreux, Archives départementales de l'Eure, H 91, fol. 77r, printed with some errors in Potter, “The Friendship Network of Le Bec", II, no. 418. The act is witnessed by Froger, bishop of Sées, Robert de Neubourg, dean of Évreux, and his uncle, Rotrou, archdeacon of Rouen.

122 Potter, "The Friendship Network of Le Bec”, II, no. 264. Marnever, Orne, cant. La Ferté-Frênel, com. Couvains.

${ }^{123}$ Glos-la-Ferrière, Orne, cant. Rai. For the family of Glos, see Crouch, The Beaumont Twins, pp. 106-07.

${ }^{124}$ On the lineage of Fresnel, see Lemoine-Descourtieux, La frontière normande de l'Avre, pp. 137-38.

${ }^{125}$ For the suggestion that Roger was related to Rotrou, see Cartulaire de Beaumont-le-Roger, p. 43, note 5.

${ }^{126}$ Potter, "The Friendship Network of Le Bec", II, no. 424. Le Theil-Nolent, Eure, cant. Beuzeville.
} 
priest (sacerdos) of La Londe, for which no such connection can seemingly be found. ${ }^{127}$ Much the same is true of the entries relating to members of the middling and lower clergy in the Le Bec necrology. Some, such as the aforementioned Joscelin Crispin, are specifically identified as benefactors, but others, like John Paynel, who was a deacon and archdeacon of Coutances in the mid-13th century, appear without further explanation. The son of Fulk II Paynel ( $†$ before 1230), whose family established the abbey of Hambye, John was himself a man of connection and influence. ${ }^{128} \mathrm{He}$ is the only individual of purely archidiaconal rank listed in the necrology, but whether he owed his commemoration to an act of patronage is unknown. ${ }^{129}$ His inclusion nevertheless bears witness to the abbey's continued reputation, which in the 1250s was still seemingly strong enough to attract men of John's calibre, whose own zone of influence and power, located principally in the Cotentin, lay far from that of Le Bec's.

Moreover, if the evidence relating to benefaction by ecclesiastics of this rank is meagre at best, the patterns that can be identified reveal once again the extent to which Le Bec's web of patronage exploited the spiritual and secular networks that underpinned much of medieval society. Just as certain families counted among the abbey's most generous benefactors, transmitting the tradition of patronage from one generation to the next, as the chapter in this volume by Julie Potter makes clear, so it seems that certain religious corporations, such as the cathedral chapter of Évreux, also cultivated among its members a sense of obligation towards the abbey. Of course, ties of kinship with other Le Bec patrons played an important part in this, while members of the ecclesiastical hierarchy, unlike their secular counterparts, often

\footnotetext{
127 Évreux, Archives départementales de l'Eure, H 54, printed in Mémoires et notes, II, 391-92. La Londe, Seine-Maritime, cant. Elbeuf; Martot, Eure, cant. Pont-de-l’Arche.

${ }^{128}$ For John, see Early Yorkshire Charters, VI, 28; Grant, Architecture in Normandy, p. 174.

${ }^{129}$ It is possible that John was somehow connected to Le Bec via the chapter at Évreux, since he is also listed in the cathedral's necrology; see "Ex obituario ecclesiae Ebroicensis", p. 461.
} 
had little choice but to interact with the monastic institutions of their diocese. Bishops, by the very nature of their office, were required to perform ceremonies such as dedications and blessings, or resolve disputes, during which the monastic community might petition them to make or confirm gifts. It should also come as little surprise that many of those abbots who had begun their career at Le Bec should have continued to maintain close links with the abbey, or that those priests responsible for churches in Le Bec's possession should look to make gifts in its favor.

But it should also be remembered that Le Bec did not exist in a vacuum. Even in the 11th century, it represented just one of many monastic institutions in the region, some of which could trace their origins to the pre-Norman period (Jumièges, Saint-Wandrille, SaintOuen de Rouen), and all of which were competing for patronage. Le Bec's association with Lanfranc and St Anselm initially gave the abbey a distinct advantage in this regard, albeit one that began to fade with their passing, while the creation and rapid expansion of the new monastic orders in the 12 th century only sought to increase this competition. Despite such pressures, however, Le Bec continued to attract donations from ecclesiastical figures of every rank, as the above has hopefully demonstrated. It also used the opportunity to forge spiritual links with various Cistercian and Augustinian houses, ${ }^{130}$ to whom the abbey's more remote (and thus more difficult to administer) possessions might occasionally be granted in return for important revenues. ${ }^{131}$ The 13th century began and ended with massive building works on the

\footnotetext{
${ }^{130}$ The list of houses in confraternity with Le Bec contains four Augustinian institutions (Saint-Gaultier, SaintQuentin de Beauvais, Saint-Jean-en-Vallée-lès-Chartres, York) and three Cistercian ones (Savigny, Notre-Dame de Molesme and Villers-la-Ville). The abbey also counted Fontevraud and Tiron among its spiritual friends; see Potter, "The Friendship Network of Le Bec”, I, 325-26 (Appendix D).

${ }^{131}$ In 1196, Abbot Walter (1195-97) granted to the Cistercian abbey of Chaalis the rights that Le Bec held at Sainte-Eusoye (Oise, cant. Saint-Just-en-Chaussée), Nucourt (Val-d'Oise, cant. Pontoise) and Auvillers (Oise, cant. Mouy, com. Neuilly-sous-Clermont), as well as in the castellany (castellania) of Breteuil (Oise, chef-lieu
} 
abbey church, brought on by fire and collapse, ${ }^{132}$ but the community continued to thrive, and, when Eudes Rigaud, archbishop of Rouen (1248-75), visited in 1251 he noted that everything was "in good order" (in bono statu). ${ }^{133}$ It was a typically tight-lipped assessment from this notoriously difficult-to-please prelate, but it was one that would have no doubt satisfied Le Bec's founder, as well as its many ecclesiastical patrons.

de cant.), in return for an annual rent of two silver marks payable to the Bec monks at Saint-Aubin-sous-Erquery (Oise, cant. Clermont); see Paris, Bibliothèque nationale de France, MS Lat. 11003, fol. 340, nos. 1386, 1387. ${ }^{132}$ Histoire, I, 544-45, 617-19.

${ }^{133}$ Regestrum visitationum archiepiscopi Rothomagensis, p. 104. 


\section{Appendix: William Bona Anima's grant to the Abbey of Le Bec (c.1 June 1091, Rouen).}

In the time of Duke Robert, son of William, king of the English, William [Bona Anima], archbishop of Rouen, for the sake of his soul, and those of his predecessors and successors, declares to the abbey of Le Bec and to Abbot Anselm, out of reverence for that place and for the religious life of the monks, that the church of Le Bec, its parish, and its parishioners shall be free in perpetuity from all episcopal exactions, except in cases where the intervention of the bishop is necessary, such as the ordination of monks or clerics; the reconciliation of churches; the giving of public penance; the reconciliation of penitents; private penance, which must not be performed without the archbishop's counsel; and the distribution of the chrism and holy oil. Put briefly, the archbishop vows to undertake his pastoral duties with regards to the abbey and the abbot without accepting payment. If a case should arise in the parish that requires ordeal by iron, it will be up to the abbot to prescribe whether the procedure is to be held in the mother church [i.e. the cathedral of Rouen], or to ask the archbishop to send the iron to the parish, along with his ministers, who will judge the case. Whatever fines are levied as a result will be paid to the abbot. The parish priest is to come to synod to hear the archbishop's commands, and if during this synod he is found to have acted against his order, he will be required to post surety (vadimonium). The priest may speak to the abbot on this matter, and either the abbot or one of his men will represent him, but if the priest is unable to prove (deratiocinare) his case, then he will make satisfaction to the archbishop. In all the other parishes in the diocese of Rouen belonging to Le Bec, those lay members of the abbey's household who possess neither houses nor lands will also be free [from episcopal exactions]. However, if one of these individuals should act against the Christian faith and the abbot fails to correct him, then the archbishop will admonish him to do so; if the abbot refuses, the archbishop will punish the individual himself. In return, the abbot agrees that, without good reason, he is to go when invited by the archbishop to the 
dedication feast of the church [of Rouen]. He will be lodged at the archbishop's expense and will take part in the mass celebrated by the archbishop in the choir. If the archbishop, for whatever reason, is unwilling or unable to celebrate this mass, then the abbot will officiate in his place. This has been settled in consultation with the archbishop's clerks. Moreover, the abbot agrees to quiet, in consultation with his monks, the plaints and claims that he had made in certain of the aforementioned churches, and to concede to the archbishop all the episcopal customs in whatever the abbey already possesses, or will acquire thereafter, in the diocese of Rouen outside the parish of Le Bec.

\section{A. Original lost.}

B. 17th-century abbreviated copy by Dom Thibault, MS Lat. 12884, fols. 68v-69v (no source, probably from $A$ ); $C$. 18th-century abbreviated copy by Dom Jouvelin, MS Lat. 13905 , fol. 52 r (corrections to $a$ and witness list, probably from $A$ ); $D$. 19th-century copy by the abbé Porée, Évreux, Archives départementales de l'Eure, 3 F 424, fol. 50r (from $C$ ).

Printed: $a$. Lanfranc of Le Bec, Opera omnia, p. 332 (no source, without witness list); $b$. Gallia Christiana, XI, 17-18 (Instr.) (from $a$, abbreviated and without witness list); c. PL, CV, 552-54 (no source, without witness list); $d$. Haskins, Norman Institutions, p. 68 (= no. 8) (from $C$, witness list only); e. Regesta, II, 400 (= no. 317b, "Errata and addenda to Volume 1") (from $C$, witness list only).

Ind.: Château de Semilly, coll. Mathan, LXX, p. 115; Paris, Bibliothèque nationale de France, MS Nouv. acq. fr. 21807, fol. 178; Évreux, Archives départementales de 1'Eure, 3 F 422, fol. 5; De Rémusat, Saint Anselme de Cantorbéry, p. 90; Histoire, I, 319-21; Haskins, Norman Institutions, p. 68; Lemarignier, Étude sur les privilèges, p. 172; Vaughn, The Abbey of Bec, pp. 38-39; Chibnall, "From Bec to Canterbury", p. 26; Gazeau, "Le domaine continental du 
Bec”, p. 264; Vaughn, Anselm of Bec, pp. 61-62; Gazeau, "Notices biographiques", p. 97; Gazeau, Normannia monastica, I, 114; ibid., II, 44, notes 83, 81; Treatises, p. 18.

Note. The source for D'Achery's edition (a) is unclear, but it is perhaps a lost original, which is catalogued in a 17 th-century inventory. ${ }^{134}$ On the other hand, a copy of this act was once found in a 13th-century cartulary of Le Bec, a fragment of which is today conserved at the Archives de l'Eure. ${ }^{135}$ Dom Jouvelin, who not only provides a witness list but also corrections to D'Achery's printed edition, seems to have worked from the same source, and the witness list in particular has many features that are common to original documents. The witnesses, for example, are placed in no discernible order, while the manner in which the crosses are scattered is reminiscent of an original charter. The names begin in three columns, but from the signum of the abbot of Saint-Wandrille onwards, this is reduced to two. The reading here is left to right throughout. Haskins ignored the order and rearranged the signa so that all the ecclesiastical witnesses appear in order, or are grouped by institution. However, even if one reads left to right for the witnesses in three columns and then top to bottom for those in two, some ecclesiastical signa appear after those of their lay counterparts. The crosses, which Haskins did not print, are generally placed below the witnesses names, either towards the middle or the end. Sometimes, however, they are deliberately inserted mid-word. It is possible that this charter was issued at or soon after the council of Rouen held shortly

\footnotetext{
${ }^{134}$ Paris, Bibliothèque nationale de France, coll. Cinq-cents de Colbert, CXC, p. 16: "Layettes 1 et 2, cottée $103 "$.

${ }^{135}$ Only a part of the table of contents remains in Évreux, Archives départementales de l'Eure, 2 F 2121, fol. 7v, which includes the following entry: Tituli Roth(omagensium) archiepiscoporum. Carta Guill(el)mi Rothom(agensis) archiepiscopi de libertate quam indulsit Anselmo abbati Becci, videlicet quod extra parrochialis et omnes parrochiani de Becco sint liberi ab omni exactione episcopali exceptis solummodo [...] que non possunt administrari, sine episcopali presentia. Item de libertate concessa hominibus de manupastu nostro intra dyoc(esis) Rothmag(ensis).
} 
after 1 June $1091,{ }^{136}$ which was convened to elect Serlo d'Orgères as bishop of Sées, while some of the witnesses to this act also witnessed an act of Michael, bishop of Avranches, which was issued at Rouen in $1091 .{ }^{137}$ The charter must certainly have been granted before the departure of Nicholas, abbot of Saint-Ouen de Rouen, who left for the Holy Land at the end of 1091, dying at Nicaea on 27 February 1092. ${ }^{138}$

\section{a, corrected from $C$}

Virorum prudentium ${ }^{(a)}$ consuetudo est, et eorum maxime, qui de statu sanctae ecclesiae aliquid rationabiliter disponunt, ne per ignorantiam vel oblivionem a propria firmitate aliquando decidat, inscriptionis auctoritate ${ }^{(b)}$ firmare. Sed episcopalis curae officium est, diligenter procurare, quatinus $^{(\mathrm{c})}$ monasteria servorum Dei in pace, et quiete firmata permaneant, ne divinis officiis mancipatae mentes aliqua occassione a suo proposito impediantur. Hac igitur rationis aestimatione $\operatorname{ego}^{(\mathrm{d})}$ quoque $^{(\mathrm{e})}$ Wilielmus $^{(\mathrm{f})}$ Dei gratia Rothomagensium archiepiscopus literis mandare decrevi, tempore videlicet Roberti comitis filii Wilielmi ${ }^{(\mathrm{g})}$ regis Anglorum, quod Beccensi ecclesiae, et domno Anselmo abbati, ob reverentiam ejusdem loci, et fratrum religiosissimam vitam, sed et propter salutem animae meae, antecessorumque meorum, necnon et successorum, concedo, ut ecclesia ipsa, ejusque ipsius loci parochia, cum residentibus parochianis suis perpetuo sit libera ab omni episcopali exactione, ${ }^{(\mathrm{h})}$ praeter ea, quae absque ${ }^{(\mathrm{i})}$ episcopali officio administrari non possunt: ut est monachos vel clericos ordinare, ecclesias reconciliare, poenitentiam publicam dare, et hujusmodi poenitentes reconciliare, aut illam $^{(\mathrm{j})}$ poenitentiam occultam, quae sine consilio ${ }^{(\mathrm{k})}$ episcopi dari non potest, determinare, chrisma quoque, et oleum tribuere; ut in brevi cuncta

\footnotetext{
${ }^{136}$ Regesta, II, 400 (= no. 317b).

${ }^{137}$ Allen, "Un évêque et sa ville", pp. 44-47 (= no. III).

${ }^{138}$ Gazeau, Normannia monastica, II, 245.
} 
complectar, monasterii et abbatis, prout decet, omnem pastoralem curam gerere sine acceptione $^{(1)}$ pecuniae. Si autem in eadem parochia talis causa orta fuerit, quae ferri judicio finienda sit: tunc ex placito abbatis, aut apud matrem ecclesiam causa finietur, ${ }^{(m)}$ judiciumque portabitur; aut archiepiscopus ferrum judicii ad locum illum per ministros suos destinabit, judiciumque ibi coram archiepiscopi ministris portabitur. Quod si pecunia exierit, ubicumque judicium portatur, abbatis erit. De sacerdote quoque parochiae illius statuimus quod ad synodum veniat et archiepiscopi mandata audiet, qui si in eadem synodo aliquid contra ordinem suum fecerit, vadimonium ibi dabit, et acceptis super hoc induciis ut ad abbatem loquatur, abbas eum vel per se vel per aliquem de suis episcopali justiciae repraesentabit, et si se deratiocinari non potuerit, archiepiscopo rectitudinis judicio satisfaciet. ${ }^{(n)}$ In caeteris autem parochiis, quae ad eamdem ${ }^{(0)}$ abbatiam pertinent, et sunt de nostra diocesi, ${ }^{(\mathrm{p})}$ hoc solum ei concessimus, ut manu pastos ${ }^{(\mathrm{q})}$ suos laicos quietos habeat, illos tantummodo, qui terram, vel domos nullo modo possident. Si autem de his omnibus, quos liberos esse concessimus, aliquis contra christianitatem egerit, et abbas ad hoc corrigendum tardus extiterit, archiepiscopus eum, ut corrigat monebit: quod si abbas postea corrigere noluerit, archiepiscopus emendabit. Pro his igitur quae concessimus, abbas talem honorem, et tale servitium ecclesiae nostrae metropolitanae exhibebit: ut si ab archiepiscopo invitatus fuerit, et legitimam excusationem non habuerit, ad festum dedicationis ejusdem ecclesiae veniat, sumptus archiepiscopi habiturus, ut archiepiscopo missam celebrante chorum teneat: aut si archiepiscopus aliqua causa missam celebrare noluerit, aut non potuerit, idem abbas missam festivam pro eo celebret. Haec ${ }^{(\mathrm{r})}$ autem ex consulto clericorum nostrorum fecimus. At vero abbas ex consulto monachorum suorum querelas quasdam et calumnias, quas in quibusdam de praefatis ecclesiis faciebat, clamavit quietas, et concessit, ut omnes episcopales consuetudines habeat archiepiscopus, et in illis ecclesiis, quas tunc temporis Beccensis 
ecclesia in diocesi ${ }^{(\mathrm{p})}$ nostra possidebat ${ }^{(\mathrm{s})}$ extra Beccensem parrochiam, ${ }^{(\mathrm{t})}$ et insuper in illis omnibus, quas deinceps in diocesi ${ }^{(\mathrm{p})}$ nostra acquisitura erat. ${ }^{(\mathrm{u})}$

S. Rotberti comitis Normanniae. Sig. Wilielmi archiepiscopi Rotho-(crux)-magensis. S. Gisleberti (crux) Ebroic(ensis) episcopi. S. Gaufridi (crux) episcopi Constantiensis. S. Will(el)mi episcopi (crux) Dunelmensis. ${ }^{(v)}$ S. Odonis episcopi (crux) Baiocensis. S. Serlonis (crux) episcopi Sagiensis. S. Benedicti (crux) archidiaconi. S. Fulberti (crux) archidiaconi. S. Gisleberti scolastici. S. Rogeri fratris abbatis Cadumensis (crux) S. Girardi (crux) archidiaconi. S. Rogeri (crux) secretarii. Ricardi filii Wil(lelm)i (crux). S. Giraldi abbatis (crux) Sancti Wandregisili. S. Hugonis (crux) abbatis Cerasiensis. S. Nicholai (crux) abbatis Sancti Audoeni. S. Will(el)mi abbatis (crux) Cormeliensis. S. Gisleberti (crux) Cadumensis. S. Rotberti (crux) de Monteforti. S. Fulconis (crux) abbatis de supra Diva. S. Rotberti (crux) comitis de Mellent. S. Will(el)mi Eb-(crux)-roicensis comitis. S. Guillelmi (crux) Crispini. S. Gisleberti (crux) Crispini. S. Radulfi de Conchis.

(a) Corrected from $C$; prudentum a. - (b) Corrected from C; authoritate $a$. - (c) Corrected from $C$; quatenus $a$. - (d) B begins here - (e) quoque om. B. - (f) Corrected from $C$; Willelmus $B$ a. - (g) Corrected from $C$; Willelmi $B$ a. — (h) exactione episcopali $B .-$ (i) Corrected from $C$; ab a. - (j) Corrected from C; illa $a$. - (k) concilio B. - (l) acceptatione B. - (m) Corrected from $C$; finiatur $B$ a. - (n) De sacerdote ... satisfaciet om. $B$ a. - (o) eandem B. - (p) Corrected from C; dioecesi B a. - (q) Sic a, corr. manupastos. — (r) Hoc B. - (s) Corrected from C; possidebit B a. - (y) parochiam B. - (u) B a end here. - (v) This witness is in the left hand margin in $C$. 
Figures

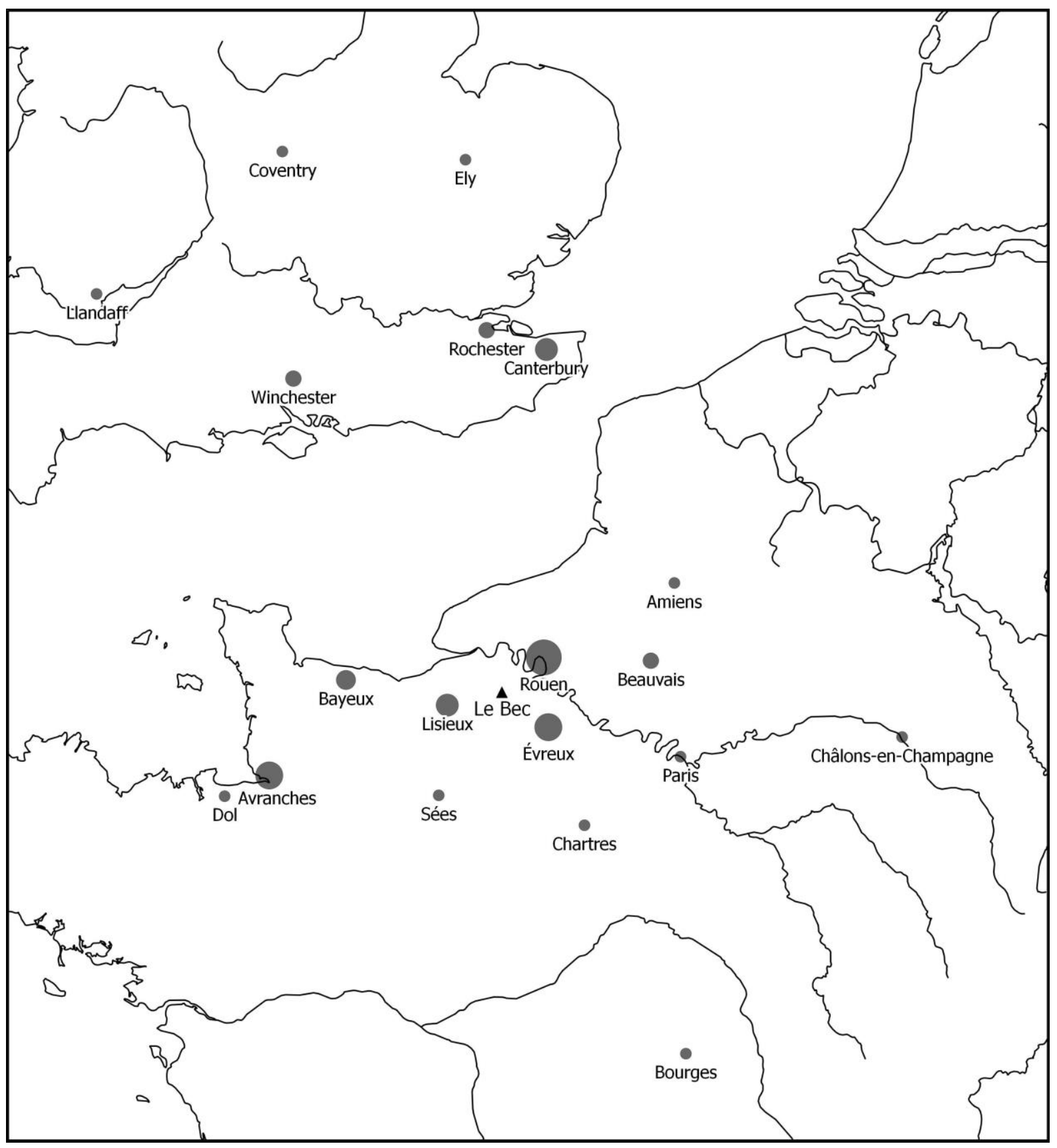

Fig. 000: Bishops commemorated in the necrology of Le Bec (11th-13th centuries) 


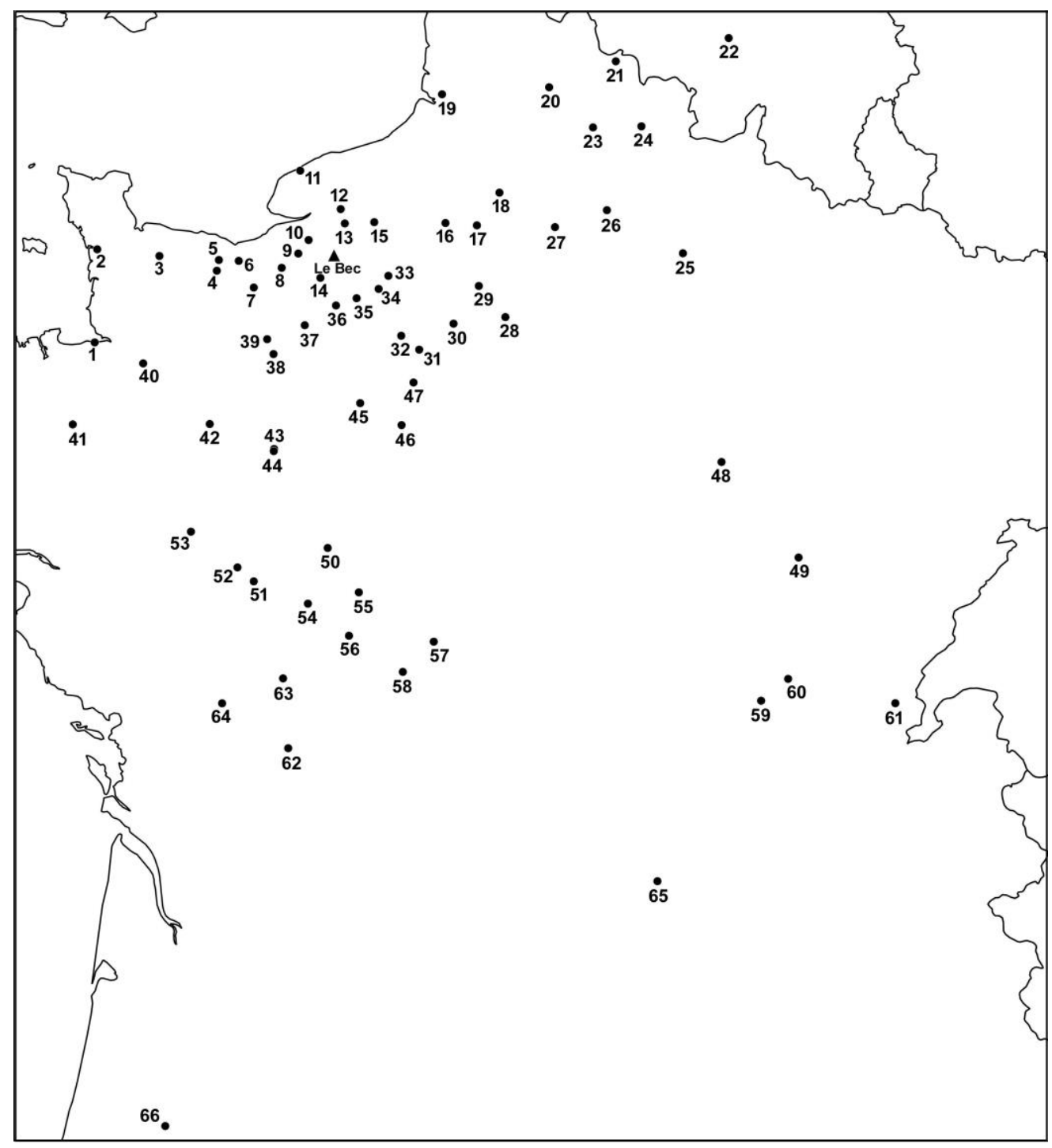

1. Mont Saint-Michel

2. Lessay

3. Cerisy-la-Forêt

4. Saint-Étienne de Fontenay

5. Saint-Étienne de Caen

6. Troarn

8. Notre-Dame-du-Pré-lès-Lisieux
7. Saint-Pierre-sur-Dive

9. Notre-Dame de Cormeilles

10. Saint-Pierre de Préaux and Saint-Léger de Préaux

11. Fécamp

12. Saint-Wandrille

13. Jumièges
14. Bernay

15. La Trinité du Mont de Rouen and Saint-Ouen de Rouen

16. Saint-Germer-de-Fly

17. Saint-Lucien, Saint-Symphorien and Saint-Quentin de Beauvais

18. Notre-Dame de Breteuil

19. Forest-Montiers

20. Saint-Vaast d'Arras

21. Saint-Amand-en-Pévèle

22. Villers-la-Ville

23. Saint-Pierre de Honnecourt

24. Saint-Étienne de Fesm

25. Saint-Remi de Reims
26. Notre-Dame de Nogent-sous-Coucy

27. Notre-Dame de Compiègne

28. Saint-Denis and Saint-Magloire de Paris

29. Saint-Martin de Pontoise

30. Saint-Pierre de Neauphle

31. Notre-Dame de Coulombs

32. Saint-Étienne de Dreux

33. La Croix-Saint-Leufroy

35. Saint-Pierre de Châtillon-lès-Conches

37. Saint-Évroult

38. Saint-Martin de Sées

39. Almenêches

41. Saint-Melaine de Rennes

42. Notre-Dame d'Evron

43. Saint-Vincent du Mans

44. Saint-Pierre de la Couture

45. Sainte-Trinité de Tiron

46. Saint-Florentin de Bonneval

47. Saint-Père de Chartres and Saint-Jean-en-Vallée-lès-Chartres

48. Notre-Dame de Molesme
49. Saint-Bénigne de Dijon

50. Marmoutier

51. Fontevraud

52. Saint-Florent de Saum

53. Saint-Serge d'Angers

54. Notre-Dame de Noyers

55. Sainte-Trinité de Beaulieu-lès-Loches

56. Saint-Pierre de Preuilly

57. Notre-Dame de Déols

58. Saint-Gaultier

60. Saint-Philibert de Tournus

61. Saint-Oyand de Joux

62. Saint-Sauveur de Charroux

63. Saint-Cyprien de Poitiers

64. Saint-Maixent

66. Saint-Sever

Based on Paris, BnF, ms. lat. 13905, fol. 73r-v

Not included: S. Mariae coenobii iuxta Ligerim

Fig. 000: Monastic communities (France and Belgium) in confraternity with Le Bec 